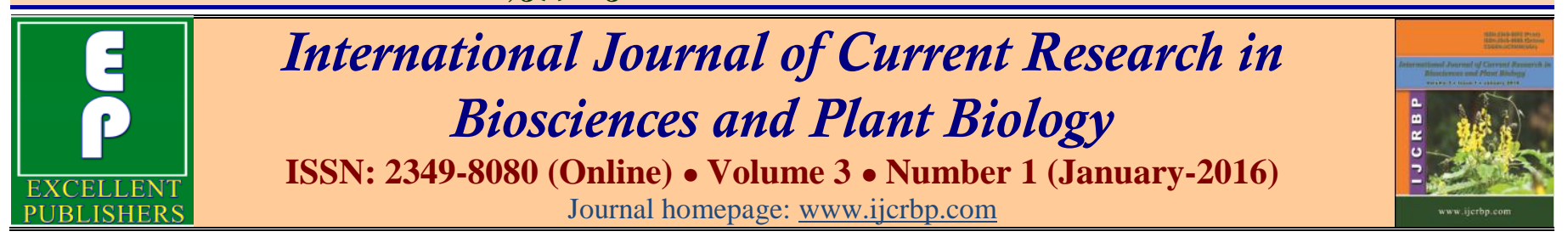

Review Article

doi: http://dx.doi.org/10.20546/ijcrbp.2016.301.012

\title{
The Effect of Hormones on the Quality of Poultry Meat
}

\author{
Serikbayeva Asiya and Ospanova Akzira* \\ Faculty of Technology and Biological Resources, Kazakh National Agrarian University, Almaty, Kazakhstan \\ *Corresponding author.
}

\section{Abstract}

The use of substances having hormonal or thyrostatic action as well as b-agonists is banned in the world. However, sometimes forbidden drugs may be added to feeds for illegal administration to farm animals for promoting increased muscle development or increased water retention and thus obtain an economical benefit. The result is a fraudulent overweight of meat but, what is worse, residues of these substances may remain in meat and may pose a real threat to the consumer either through exposure to the residues, transfer of antibiotic resistance or allergy risk. This has exerted a great concern among consumers. Poultry products are some of the most important sources of protein in the world. Even though poultry is considered a healthy meat type, there are wide concerns regarding chemical contamination in poultry products. An important part of raising chickens is feeding - feeding makes up the major cost of production and good nutrition is reflected in the bird's performance and its products. This publication discusses the Poultry production and about hormones in poultry feed, analytical method for determine hormones. Why poultry feed? Because feed causes direct impact to food that originated from poultry products. Feeds and feed additives an important link in poultry, directly influence quality and safety of poultry products.
\end{abstract}

\section{Article Info}

Accepted: 07 December 2015

Available Online: 06 January 2016

\section{Keywords}

17-b estradiol

Chemical contamination

Hormones

Poultry feed

Poultry meat

Residues

Steroid

\section{Introduction}

In recent years, hormones and hormone like substances have been recently used in livestock production to obtain a high yield performance in a shorter period of time. These anabolic agents are used to increase the weight gain, to improve the food efficiency, storing protein and to decrease fatness. However, depending on the use of anabolic agent in animal feed, anabolic residues that mayo ccur in meat and meat products present risks to human health. The question of the use in animal production of anabolic agents, including the natural steroid hormones and their derivatives, has been-and continues to be-badly stated, and therefore misunderstood. Those who brought the problem before the public had neither the information nor the technical competence, especially in biology, to speak with perfect objectivity. Hormones are found naturally in many animal products (Ferrando et al., 1960; Loraine and Trevor Bell, 1976) and, as phytohormones, in many plants (Fernando, 1978 and 1979). Only some of them raise public health problems, and these should be distinguished from the others. Indeed, a study of the practical and health aspects of the use of hormones in animal production should underlie all regulation of the matter, and therefore any decision on the measurement of hormone levels.

Hormone-ward sex contrasts in development rate have been known for quite a while. It has likewise been realized that development rate and FCE (bolster change proficiency) are higher in place guys than in maims. It was common, then, that the accessibility of hormones and other characteristic or engineered substances 
showing hormonal action prompted trials going for their utilization to build creation. Starting in the mid-1950s, DES (diethylstilboestrol) and hexoestrol were regulated to steers progressively in the US and the UK individually, either as food added substances or as inserts, and different sorts of substances additionally steadily got to be accessible. When all is said in done, such treatment has brought about $10-15 \%$ increments in every day increases, comparable enhancements in FCE and change of corpse quality (expanded incline/fat proportion). Therefore there has been a significant lessening in the measure of vitality required per unit weight of protein delivered (Preston, 1975), and the monetary ramifications of this have been extraordinary.

While the utilization of hormonally dynamic substances in creature generation rose, restriction to their utilization additionally expanded, due to the hypothetical plausibility that deposits in eatable tissues may jeopardize shoppers. The components prompting the prohibition on DES in the US, initially forced in 1973, have been portrayed (Umberger, 1975). A few reports affirm that DES jeopardizes the strength of creatures and man, when more than once utilized as a part of extensive dosages (Roe, 1976). In any case, as respects dangers because of the vicinity of deposits in meat delivered by, no recorded harmful impacts have ever been accounted for in man, either from DES or whatever other substance with hormonal movement. A qualification ought to be made between the hormones in that capacity, for which the digestion system in the body is moderately surely understood, and engineered or different substances for whose metabolic inactivation the body may not have the compounds essential. At the point when characteristic hormones are utilized as a part of creature generation, cases of zero-resilience buildup levels are not significant, since these mixes happen in noticeable and very variable focuses in body liquids and also in the tissues of all creatures, treated or not (Weerden and Grandadam, 1976). For different substances with hormonal action the circumstance is distinctive. On the other hand, when buildup levels are to a great degree low, it appears to be sensible to measure the potential dangers against the undisputed beneficial outcomes some of these mixes have in creature protein generation.

\section{Poultry production, consumption and risk perceptions on contamination of poultry products}

Worldwide production of chicken meat in 2010 exceeded 74 million metric tons of ready to eat meat, while world egg production in 2009 was estimated at over 62 million metric tons (compared with 106 million metric tons of pork and less than 65 million metric tons of beef in 2010 (WATT, 2011). China is the biggest chicken meat producer in the world, while the EU is the biggest producer of turkey meat in the world, with a combined production of over 1800 million metric tons of ready to cook equivalent meat. Consumption of poultry products has increased in recent times as a result of the financial recession, as consumers stayed away from more expensive cuts. The country with the highest consumption of chicken meat in the world is the US (over $50 \mathrm{~kg} /$ capita/year) (Magdelaine et al., 2008).

Average annual per capita chicken meat consumption varies significantly across the world, with small island countries in Central America (such as Antigua/Barbuda, Saint Kitts and Nevis, and Saint Lucia) consuming as much as $60 \mathrm{~kg} /$ per person while Asian countries such as Thailand eat only $15 \mathrm{~kg}$ a year (approximately $40 \mathrm{~kg}$ in Hong Kong and Taiwan). Interestingly, consumption of chicken meat in India tends to be very low, with less than $1 \mathrm{~kg}$ per person per year being reported; however, it is the fastest growing segment of agriculture in the country (FAOSTAT, 2010).

In the European Union, the highest per capita chicken consumption rates are in Hungary and Ireland, and the lowest in Sweden and Finland (Magdelaine et al., 2008). Global egg consumption decreased significantly in the last part of the twentieth century due to concerns about cholesterol content, but lately it has started to recover. Similarly to meat consumption, annual per capita egg consumption varies widely around the world, with a range from about 450 eggs a year in Mexico (WATT 2011), to 250 in the US (ERS, 2009), to about seven eggs per person in India (FAOSTAT, 2010).

China consumes approximately $40 \%$ of the world egg production each year (FAOSTAT, 2010). In general, poultry products are perceived as healthy, nutritious, convenient, versatile and inexpensive foods (Yeung and Yee, 2002; Kennedy et al., 2004). Additionally, recent food scares such as Bovine Spongiform Encephalopathy (BSE) in 1996 and the 2001 Foot-and-Mouth (FMD) crisis have had a lasting negative effect on consumers' perception of red meat and given a significant boost to poultry consumption (Kennedy et al., 2004). Yet, consumers are noticeably concerned about contamination in poultry products, particularly meat (Yeung and Morris, 2001). Approximately half of the consumer population identified raw or undercooked poultry meat as the most important food source for foodborne pathogens 
(particularly Salmonella and Campylobacter (FSA, 2001). Nonetheless, even though some consumers did express concerns regarding chemical contamination and residues in poultry meat, it is usually considered to be safer than all other meat products (Yeung and Yee, 2002; Kennedy et al., 2004).

Interestingly, one of the main concerns regarding chemical contamination in poultry meat is the purported use of artificial hormones. Any internet search will show that artificial hormones in chicken products have been blamed for anything from acne and baldness to precocious puberty and homosexuality. In reality, hormones are prohibited for use in poultry production in most countries (Verbeke et al., 2007). They are not used in poultry production because they may cause unfavorable effects on animal production and health, such as increased fat deposition in and around organs and muscle, and reduced muscle development due to a decline in protein biosynthesis in the birds (Vasilatos Younken, 1995; Chen et al., 2010). Unfortunately, consumers tend to associate risks from one type of food product with others, and thus reports on use of hormones in beef and dairy production can lead to generalizations and misconceptions that affect other products, such as poultry (Bruhn, 1999).

\section{Hormonal preparations used in poultry production}

Hormones are chemicals produced by animals to coordinate their physiological activities. They act as messengers, produced in and released from one kind of tissue to gradually stimulate or inhibit some process in a different tissue over a long period. Steroid hormones fulfill an important role at different stages of mammalian development comprising prenatal development, growth, reproduction and sexual and social behavior. The importance of individual hormones varies between sexes and age and a disruption of the endocrine equilibrium may result in multiple biological effects. One hormone can have multiple actions, e.g. the male hormone testosterone controls many processes from the development of the foetus, to libido in the adult. Alternatively, one function may be controlled by multiple hormones, e.g. the menstrual cycle involves oestradiol, progesterone, follicle-stimulating hormone and luteinising hormone. Hormones produced by the bodies of humans and animals are called endogenous or natural hormones. Compounds chemically synthesised to mimic the effect of natural hormones are called synthetic or xenobiotic hormones. Hormones are vital in normal development, maturation and physiological functioning of many vital organs and processes in the body. However, like any other chemicals of natural or synthetic origin, hormones may be toxic to living organisms under certain circumstances. The toxicity may be due to an excess of its normal ('physiological') action. This may be the result of excessive exposure to the substance, for example following absorption of a large dose, or because the physicochemical nature of the substance gives it greater or more prolonged activity of the same type, or because the hormonal action occurs at an abnormal time during development or adult life, or is an action on an organism of the inappropriate sex. Hormones, like other chemicals, may also exert direct toxic actions not related to their endocrine ('physiological') effects. Due to the obvious ability to improve weight gain and feed efficiency in meat producing animals, natural hormones and/or the synthetic surrogates have been used in agricultural practice for several decades (Table 1).

Implanting hormonal growth promoters is currently widespread in the beef cattle industry of many non-EU countries for the better performance in growth and improvement of feed efficiency. These hormonal implants may enhance growth during suckling, growing and finishing stages of production (Mader, 1997; Platter et al., 2003). Growth hormones are implanted under the skin (usually behind the ear) of the animal in the form of depot capsules, where they release a specific dose of hormones over a fixed period of time. The five hormone types most widely used in meat production include three natural hormones, estradiol $17-\beta$, testosterone, and progesterone, and two synthetic substances, trenbolone and zeranol. Estradiol $17-\beta$ has estrogenic action (i.e. responsible for female characteristics); testosterone has androgenic action (i.e., responsible for male characteristics); and progesterone has gestagenic action (i.e. responsible for maintaining pregnancy). The other two hormones, as aforesaid, mimic the biological activity of the natural hormones: trenbolone mimics the action of testosterone, and zeranol mimics estradiol 17- $\beta$.

Implanting hormonal growth promoters is currently widespread in the beef cattle industry of many non-EU countries for the better performance in growth and improvement of feed efficiency. These hormonal implants may enhance growth during suckling, growing and finishing stages of production (Mader, 1997; Platter et al., 2003). Growth hormones are implanted under the skin (usually behind the ear) of the animal in the form of depot capsules, where they release a specific dose of hormones over a fixed period of time. The five hormone types most widely used in meat production include three 
natural hormones, estradiol $17-\beta$, testosterone, and progesterone, and two synthetic substances, trenbolone and zeranol. Estradiol 17- $\beta$ has estrogenic action (i.e. responsible for female characteristics); testosterone has androgenic action (i.e. responsible for male characteristics); and progesterone has gestagenic action (i.e. responsible for maintaining pregnancy). The other two hormones, as aforesaid, mimic the biological activity of the natural hormones: trenbolone mimics the action of testosterone, and zeranol mimics estradiol 17- $\beta$.

Table 1. Hormonally-active substance used in animal production (by http://www.fao.org/DOCREP/004/X6533E/X6533E01.htm, modified).

\begin{tabular}{|c|c|c|c|}
\hline Substances & Dose levels & Form & Main use - Animals \\
\hline \multicolumn{4}{|l|}{ Oestrogens alone: } \\
\hline$\overline{\mathrm{DES}}$ & $10-20 \mathrm{mg} /$ day & Feed additive & Steers, heifers \\
\hline DES & $30-60 \mathrm{mg} /$ day & Implant & Steers \\
\hline DES & & Oil solution & Veal calves \\
\hline Hexoestrol & $12-60 \mathrm{mg}$ & Implant & Steers, sheep, calves, poultry \\
\hline Zeranol & $12-36 \mathrm{mg}$ & Implant & Steers, sheep \\
\hline \multicolumn{4}{|l|}{ Gestagens alone: } \\
\hline$\overline{\text { Melengestrol acetate }}$ & $0.25-0.50 \mathrm{mg} / \mathrm{day}$ & Heifers & \\
\hline \multicolumn{4}{|l|}{ Androgens alone: } \\
\hline$\overline{\mathrm{TBA}}$ & $300 \mathrm{mg}$ & Implant & Heifers, culled cows \\
\hline \multicolumn{4}{|l|}{ Combined preparations: } \\
\hline $\mathrm{DES}+$ & $25 \mathrm{mg}$ & & \\
\hline Testosterone & $120 \mathrm{mg}$ & Implant & Calves \\
\hline DES + Methyl-testosterone & & Feed additive & Swine \\
\hline Hexoestrol + & $30-45 \mathrm{mg}$ & & \\
\hline TBA & $300 \mathrm{mg}$ & Implant & Steers \\
\hline Zeranol + & $36 \mathrm{mg}$ & & \\
\hline TBA & $300 \mathrm{mg}$ & Implant & Steers \\
\hline Oestradiol-17 $\beta+$ & $20 \mathrm{mg}$ & & Bulls, steers \\
\hline TBA & $140 \mathrm{mg}$ & Implant & Calves, sheep \\
\hline Oestradiol- $17 \beta$ benzoate + & $20 \mathrm{mg}$ & & \\
\hline Testosterone propionate & $200 \mathrm{mg}$ & Implant & Heifers, calves \\
\hline Oestradiol- $17 \beta$ benzoate + & $20 \mathrm{mg}$ & & \\
\hline Progesterone & $200 \mathrm{mg}$ & Implant & Steers \\
\hline
\end{tabular}
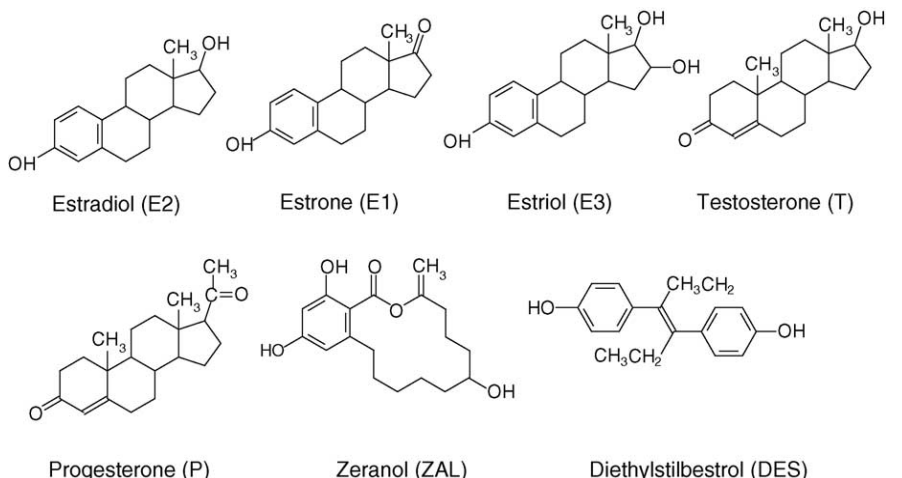

Fig. 1: Chemical structures of target hormones.

\section{Economic implications of the use of hormones in poultry production}

In the production of meat for human consumption, a hormonally-induced increase in growth rate of the order of $10 \%$ evidently has major economic implications. The improvement in FCE which usually accompanies the increase in gain adds to the economic benefits, and at the same time makes possible greater production of edible protein per unit energy used, and this in itself is of importance in a world lacking in protein supplies. Some of the hormones that have become available recently appear on average to increase gain as well as FCE considerably beyond the $10 \%$ level, and in examining whether they should be approved for use in animal production, the risk/benefit analysis must take this fact into account.

Availability of the various feeds, variations in feed and product prices as well as in types of management from time to time and from place to place may play an important role. Lowering or halting hormones use in poultry production could have serious economic effects on the poultry industry. However, shortening the time required for producing a certain weight at slaughter will represent an economic advantage, especially under feedlot conditions, since non-feed costs also contribute 
significantly to the total cost of production (600 to 1200 tenge per head per day in the Kazakhstan).

\section{The use of hormones in poultry feed}

Hormones are chemicals that transfer information and instructions between cells in animals and plants. They regulate growth and development, controlling the function of various tissues. Like antibiotics, hormones can be produced and placed in animal feed.

The use of hormones in animal feed has been a controversial topic for many years. There are obvious advantages and disadvantages with the use of such products. Farmers see hormones as a major advantage as the increase their profits and gain the maximum out of their poultry. However, health concerned organizations want to ban the use of these products due to the increasing fears that they can cause harm to the consumers. Farmers are particularly keen on feeding poultry hormones for production enhancement, namely to promote growth. Once poultry bird reaches a certain weight it can be sold to a slaughterhouse. Growth enhancing hormones cause the poultry to reach this weight at a faster rate. This is highly beneficial as it can increase the profits of the farmer as more poultry can be sold every year. As the poultry reach the weight requirement faster the cost of breeding of them also decreases. The farmer can now sell more poultry at a much lower price. This also can be of benefit to the consumer as the meat comes at a cheaper price.

'For every dollar spent on hormone implants, there are returns of seven to ten dollars to the farmer'. For example, some farmers use RBGH (recombinant growth hormone) to increase their cows' milk output production. There are a variety of other hormones that can be used but they are mainly for the purpose of raising their animal's faster and more efficiently thus reducing costs for the consumer. From the above it can be assumed that the use of hormones in poultry feed is a great advantage to the farmers allowing the production of low expense (www.westonaprice.org/farming/hormones).

\section{Analytical method for determine hormones}

\section{Chromatographic techniques}

High performance thin-layer chromatography (HPTLC) has been applied successfully for the qualitative and quantitative detection of multi-residues in food samples even though its use has rapidly decreased during the last decade. Visualization of the components can be performed either by spraying an appropriate chromogenic reagent or under UV light. Quantitative determination is possible through the relative intensity of the spot in the plate, which is measured against that of the internal standard by scanning densitometry. Recent developments allow for automation in a similar way to HPLC with the appropriate equipment. HPTLC has been applied to different residues like thyreostatic drugs (De Wasch et al., 1998), clenbuterol and other agonists (Degroodt et al., 1991), nitroimidazol (Gaugain and Abjean, 1996) and sulfonamides (Van Poucke et al., 1991) in animal tissues.

Table 2. Global population, feed manufacture and per capita us [by Feed International 2002 World Feed Panorama Survey (2001 data)].

\begin{tabular}{llll}
\hline $\begin{array}{l}\text { Year } \\
\text { (million } \\
\text { tons) }\end{array}$ & $\begin{array}{l}\text { Population } \\
\text { feed use }\end{array}$ & $\begin{array}{l}\text { Manufactured } \\
\text { feed }\end{array}$ & $\begin{array}{l}\text { Per capita } \\
\text { (billions) } \\
\text { (kg/person) }\end{array}$ \\
\hline 1975 & 4.1 & 290 & 71 \\
1980 & 4.5 & 370 & 82 \\
1985 & 4.9 & 440 & 90 \\
1990 & 5.3 & 537 & 101 \\
1995 & 5.6 & 590 & 105 \\
1996 & 5.7 & 597 & 105 \\
1997 & 5.8 & 605 & 104 \\
1998 & 5.9 & 575 & 97 \\
1999 & 6.0 & 586 & 98 \\
2000 & 6.1 & 591 & 97 \\
2001 & 6.2 & 597 & 96 \\
\hline
\end{tabular}

Table 3. Top 10 feed producing countries by region [by Feed International 2002 World Feed Panorama Survey (2001 data)].

\begin{tabular}{ll}
\hline Region & Output (milliontonnes) \\
\hline Asia & 132.0 \\
LatinAmerica & 65.5 \\
EuropeanUnion & 116.5 \\
Non-EU Europe & 48.5 \\
MiddleEast/Africa & 24.0 \\
NorthAmerica & 160.0 \\
Total & 546.0 \\
\hline
\end{tabular}

It has also been applied to the analysis of corticosteroids (Vanoosthuyze et al., 1993) and antibiotics in milk (Choma et al., 1999; Van Poucke et al., 1991). The spots can be a variation, named TLC bioautography, consists in the combination of thin-layer chromatography with microbiological detection directly on the plate resulting in enhanced sensitivity. It has been applied to the detection of flumequine in milk (Choma et al., 1999). The main advantages and disadvantages of HPTLC are compiled in Table 4. 
Table 4. Main advantages and disadvantages of HPTLC (Toldra and Reig, 2006).

\begin{tabular}{ll}
\hline Advantages & Disadvantages \\
\hline High number of samples for a single analytic & Expertise required \\
Reduced time (few hours) to obtain the results & Need of sample preparation (extraction, filtration, etc.) \\
$\begin{array}{l}\text { Possibility of automatization for higher productivity } \\
\text { Sensitive }\end{array}$ & Interferences giving some false positives \\
$\begin{array}{l}\text { Specificity depending on the detection technique } \\
\text { Separated sample can be recovered for further confirmatory } \\
\text { analysis }\end{array}$ & \\
\hline
\end{tabular}

The use of high performance liquid chromatography (HPLC) expanded during the 1990s and the availability of automation somehow facilitated its use as a screening technique. HPLC is a superlative technique and its ability to detect compounds depends on the type of detector used. The choice of the detection system is very important for selectivity and sensitivity. Some analysts not detected by absorbance, refractive index or fluorescence may require chemical modifications to render chromosphere, fluorescent or UV-absorbing compounds (Bergweff and Schloeser, 2003).

Usually, the detection of multi-residues is based on a solid-phase extraction cleanup followed by filtration and injection into a reverse phase HPLC with UV-diode array detection. It has been applied for detection of antibiotics in meat, kidney andmilk (Cinquina et al., 2003; Kirbis et al., 2005), veterinary drugs in eggs, milk, fish and meat (Aerts et al., 1995; Horie et al., 1998), methyl thiouracils in urine (Reig et al., 2005), anabolic steroids in nutritional supplements and urine (De Cock et al., 2001) and corticosteroids like dexamethasone in water, feed and meat (Mallinson et al., 1995; Reig et al., 2005; Stolker et al., 2000). A good number of substances with anabolic properties, that can be considered as growth promoters, have been successfully separated and identified for screening purposes in urine (Koole et al., 1999). HPLC with fluorescence detection has also been used for the simultaneous determination of 10 quinolone antibacterial residues in multispecies animal tissues (Verdon et al., 2005). The main advantages and disadvantages are compiled in Table 5.

Table 5. Main advantages and disadvantages of HPLC (Toldra and Reig, 2006).

\begin{tabular}{ll}
\hline Advantages & Disadvantages \\
\hline Short time (few min/sample) to obtain the results & Expertise required \\
Sensitive & Need of sample preparation (extraction and filtration, addition of \\
& internal standard, etc.) \\
Specificity depending on detector & High initial investment (equipment) \\
$\begin{array}{l}\text { Automatization leading to higher productivity } \\
\text { Possibility to find more information from spectra when } \\
\text { using diode array detector }\end{array}$ & \\
\hline
\end{tabular}

HPLC is getting expanded use in control laboratories due to the possibility to analyse simultaneously multiple residues in a sample in relatively short time. Recent developments of high speed HPLC can reduce sample treatment and analysis time. In addition, this technology is fully automated (injection, elution, washing of column, detection) and computer-controlled, facilitating its use as a screening technique. The next step after initial screening with HPLC is the injection of the presumed positive samples in a system combining HPLC with mass spectrometry detection. In this sense, the coupling of high speed HPLC with MS- MS can substantially reduce the analysis time. The use of HPLC-electrospray ionisation (ESI) tandem mass spectrometry has been proposed as a simultaneous screening-confirmatory technique (Hewitt et al., 2002; Thevis et al., 2003). Other authors have used liquid chromatography-mass spectrometry with atmospheric pressure chemical ionisation (APCI) for the analysis (Maurer et al., 2004; Turnipseed et al., 2005). Both ionisation techniques facilitate the analysis of small to relatively large and hydrophobic to hydrophilic molecules and are thus very adequate for the analysis of veterinary drug residues (Bergweff and Schloesser, 2003). Both techniques have been reported to show matrix effects being ESI more susceptible than APCI (Dams et al., 2003). Another methodology based on the application of $1 \mathrm{H}$ NMR has also been proposed as a screening technique for the analysis of steroid cocktails and veterinary drug formulations administered to livestock (Lommen et al., 2002). 


\section{Immunological techniques}

The immunological methods are based on the interaction antigen-antibody which is very specific for a particular residue. The most usual technique consists in the enzyme linked-immunosorbent assay (ELISA) and the detection system is usually based on enzyme-labeled reagents. There are different formats for antigen quantification like thedouble antibody or sandwich ELISA tests and direct competitive ELISA tests. Radioimmunoassay (RIA) is basedon the measurement of the radioactivity of the immunological complex (Samarajeewa et al., 1991). Other assays have enhanced detectability by using of a luminescence detector if using a chemiluminescent compound or a fluorimeter in the case of using a fluorescent compound (Roda et al., 2003).

Today, there are many different types of ELISA kits commercially available for a large number of substances within each group B-agonists, corticoids, steroids, stilbenes, resorcylic acid lactones and several antibiotics. ELISA kits are available for a specific residue (i.e., sulphametazine) or a group of related compounds (i.e., sulphonamides). In some cases, the possibility of cross reactions must be taken into account. These kits allow the analysis of a large number of samples per kit, do not require sophisticated instrumentation, the results are available in a few hours and are quite specific and sensitive. ELISA kits have shown good performance for the analysis of antibiotic residues in meat like tylosin and tetracycline (De Wasch et al., 2001; Draisci et al., 2001; Kumar et al., 2004; Lee et al., 2001), chloramphenicol (Gaudin et al., 2003), nitroimidazoles (Huet et al., 2005) and sulphonamides (Wang et al., 2006) and also for sedatives (Cooper et al., 2004). In general, ELISA tests require some manual operation (pipetting and discarding of liquids) that is progressively replaced by automated systems. Dipstick constitutes another system which basically consists of a membrane strip with the receptor ligands. The sample with the antibiotics is applied and left to interact and, after dipping into two different solutions, the developed colour can be quantified either by comparison to a standardized colour scale or by measuring spectrophotometrically (Link et al., 2007). The mail advantages and disadvantages of ELISA are given in Table 6 .

Table 6. Main advantages and disadvantages of ELISA test kits (Toldra and Reig, 2006).

\begin{tabular}{ll}
\hline Advantages & Disadvantages \\
\hline $\begin{array}{l}\text { Easy to use } \\
\begin{array}{l}\text { Available kits for a good number of specific compounds (i.e., } \\
\text { clenbuterol, zeranol, etc.) }\end{array}\end{array}$ & $\begin{array}{l}\text { Increased costs since 2002 (more than V650 per kit) } \\
\text { Limited storage (few months) under refrigeration }\end{array}$ \\
$\begin{array}{l}\text { Availability of kits for families of compounds (i.e. agonists, stilbenes, } \\
\text { sulphonamides, etc.) }\end{array}$ & $\begin{array}{l}\text { Expensive in the case of RIA and need for waste disposal } \\
\text { Large number of samples (42) per kit for a single analyte }\end{array}$ \\
$\begin{array}{l}\text { Reduced time (few hours) to obtain the results: about 2-2.5 hrs for } \\
\text { most kits }\end{array}$ & $\begin{array}{l}\text { Interferences giving some false positives } \\
\text { High sensitivity }\end{array}$ \\
$\begin{array}{l}\text { High specificity } \\
\text { Possibility to use within the food-processing facility }\end{array}$ & \\
\hline
\end{tabular}

\section{Conclusion}

As the globalization of the nourishment business sector keeps on extending, there will be an expanding pattern towards harmonization and expanded stringency of administrative prerequisites to regulate synthetic sullying of nourishments in diverse parts of the world. The poultry business is an incredible sample of the worldwide association in sustenance creation: hereditary lines for grills and layer chickens are delivered and created in European nations and the US, however chickens or eggs are delivered to different nations for multiplication. For instance, Brazil is one of the greatest makers of live creatures and eggs on the planet, yet per capita utilization of poultry items is moderately low in that nation; most items are deliveredagain to buyers in different parts of the world. Likewise, elements for chicken food can originate from diverse nations; for case, crop items can originate from creating nations where regulations on the utilization of pesticides are distinctive from those in the US and/or Europe, and minerals can originate from nations with diverse creation norms. Moreover, buyer concerns in regards to concoction defilement in both national and imported items will likewise likely fuel the interest for manageable, common, natural and/or nearby nourishment items, which are seen as more beneficial than the economically delivered elective. It is anticipated that these option markets will keep on developing and that regulation and gauges for these generation systems will turn out to be more stringent. 


\section{Conflict of interest statement}

Authors declare that they have no conflict of interest.

\section{References}

Aerts, M. M. L., Hogenboom, A. C., Brinkman, U. A. T., 1995. Analytical strategies for the screening of veterinary drugs and their residues in edible products. J. Chromatogr. BBiomed. Appl. 667, 1-40.

Bergweff, A. A., Schloesser, J., 2003. Residue determination. In: Encyclopedia of Food F. Toldra', M. Reig Sciences and Nutrition (Eds.: Caballero, B., Trugo, L., Finglas, P.). Elsevier, London, UK. pp.254-261.

Bruhn, C.M., 1999. Consumer percetions and concerns about food contaminants. Adv. Exp. Med. Biol. 459, 1-7.

Choma, I., Grenda, D., Malinowska, I., Suprynowicz, Z., 1999. Determination of flumequine and doxycycline in milk by a simple thin-layer chromatographic method. J. Chromatogr. B. 734, 7-14.

Cinquina, A. L., Roberti, P., Gianetti, L., Longo, F., Draisci, R., Fagiolo, A., Brizioli, B. R., 2003. Determination of enrofloxacin and its metabolite. Ciprofloxacin in goat milk by high-performance liquid chromatograph with diodearray detection: optimization and validation. J. Chromatogr. A. 987, 221-226.

Cooper, J., Delahaut, P., Fodey, T. L., Elliott, C. T., 2004. Development of a rapid screening test for veterinary sedatives and the beta-blocker carazolol in porcine kidney by ELISA. Analyst. 129, 169-174.

Dams, R., Huestis, M. A., Lambert, W. E., Murphy, C. M., 2003. Matrix effects in bio-analysis of illicit drugs with LC-MS/MS: Influence of ionization type, sample preparation and biofluid. J. Amer. Soc. Mass Spectr. 14, 1290-1294.

De Cock, K. J. S., Delbeke, F. T., Van Eenoo, P., Desmet, N., Roels, K., De Backer, P., 2001. Detection and determination of anabolic steroids in nutritional supplements. J. Pharmaceut. Biomed. Anal. 25, 843-852.

De Wasch, K., De Brabender, H. F., Van Ginkel, L. A., Spaan, A., Sterk, S. S., Meiring, H. D., 1998. Confirmation of residues of thyreostatic drugs in thyroid glands by multiple mass spectrometry after thin-layer chromatography. J. Chromatogr. A. 819, 99-111.

De Wasch, K., Okerman, L., Croubels, S., De Brabander, H., Van Hoof, J., De Backer, P., 2001. Detection of residues of tetracycline antibiotics in pork and chicken meat: Correlation between results of screening and confirmatory tests. Analyst. 123, 2737-2741.

Degroodt, J.-M., Bukanski, B. W., De Groof, J., Beernaert, H., 1991. Cimaterol and clenbuterol residue analysis by HPLCHPTLC. Zeitschrift für Lebensmittel Untersuchung und Forschung, 192, 430-432.

Draisci, R., Quadri, F. D., Achene, L., Volpe, G., Palleschiand, L., Palleschi, G., 2001. A new electrochemical enzymelinked immunosorbent assay for the screening of macrolide antibiotic residues in bovine meat. Analyst, 126, 19421946.

ERS, 2009. Poultry and Eggs Background. USDA Economic Research Service. Available at: http://www.ers.usda.gov/ briefing/poultry/backgournd/htm.

FAOSTAT, 2010. FAO database, Rome. Available at: http://faostat.fao.org/

Ferrando, R., 1978. Environnement et utilisation des oestrogénes et des anabolisants en élevage et en medicine. Schweiz Arch. Tierheilk, 120, 53 and 131.

Ferrando, R., 1979. Conventional and non-conventional foods. FAO Food and Nutrition Series No. 2, Rome.

Ferrando, R., Boisselot-Lefebvre, J., Ratsimamanga, A.R., 1960. Proc. 5th Int. Congress Nutr., Washington, D.C.

Galbraith, H., 2002. Hormones in international meat production: Biological, sociological and consumer issues. Nutr. Res. Rev. 15(2), 293-314.

Gaudin, V., Cadieu, N., Maris, P., 2003. Inter-laboratory studies for the evaluation of ELISA kits for the detection of chloramphenicol residues in milk and muscle. Food Agric. Immunol. 15, 143-157.

Gaugain, M., Abjean, J. P., 1996. High-performance thin-layer chromatographic method for the fluorescence detection of three nitroimidazole residues in pork and poultry tissue. J. Chromatogr. A. 737, 343-346.

Hewitt, S. A., Kearney, M., Currie, J. W., Young, P. B., Kennedy, D. G., 2002. Screening and confirmatory strategies for the surveillance of anabolic steroid abuse within Northern Ireland. Anal. Chimica Acta. 473, 99-109.

Horie, M., Yoshida, T., Saito, K., Nakazawa, H., 1998. Rapid screening method for residual veterinary drugs in meat and fish by HPLC. J. Food Hyg. Soc. Japan. 39, 383-389.

Huet, A. C., Mortier, L., Daeseleire, E., Fodey, T., Elliott, C., Delahaut, P., 2005. Development of an ELISA screening test for nitroimidazoles in egg and chicken muscle. Anal. Chimica Acta. 534, 157-162.

Kennedy, O.B., Stewart-Knox, B.J., Mitchell, P.C., Thurnham, D.I., 2004. Consumer perceptions of poultry meat: a qualitative analysis. Nutri. Food Sci. 34, 122-129.

Kirbis, A., Marinsek, J., Flajs, V. C., 2005. Introduction of the HPLC method for the determination of quinolone residues in various muscle tissues. Biomed. Chromatogr. 19, 259265.

Koole, A., Franke, J.-P., De Zeeuw, R. A., 1999. Multi-residue analysis of anabolics in calf urine using high-performance liquid chromatography with diode-array detection. J. Chromatogr. B. 724, 41-51.

Kumar, K., Thompson, A., Singh, A. K., Chander, Y., Gupta, S. C., 2004. Enzyme-linked immunosorbent assay for ultratrace determination of antibiotics in aqueous samples. J. Environ. Qual. 33, 250-256.

Lee, K.H., Lesson, S., 2001. Performance of broiler chickens fed limited quantities of feed or nutrients during seven to fourteen days of age. Poult. Sci. 80, 446-454.

Lommen, A., Schilt, R., Weseman, J., Roos, A. H., Van Velde, J. W., Nielen, M. W. F., 2002. Application of ${ }^{1} \mathrm{D}^{1} \mathrm{H}$ NMR for fast non-targeted screening and compositional analysis 
of steroid cocktails and veterinary drug formulations administered to livestock. J. Pharmaceut. Biomed. Anal. 28, 87-96.

Loraine, J.A., Trevor Bell, E., 1976. Hormone Assays and their Clinical Application. London, New York, Churchill Livingstone. 692p.

Mader, T.L., 1997. Carryover and lifetime effects of growth promoting implants. Proc. OSU Symposium: Impact of Implants on Performance and Carcass Value of Beef Cattle. Oklahoma Agric. Exp. Stn., Stillwater, OK. pp.88-94.

Magdelaine, M.P., Spiess, Valceschini, E., 2008. Poultry meat consumption trends in Europe. World's Poult. Sci. J. 64, 5364.

Mallinson, E. T., Dreas, J. S., Wilson, R. T., Henry, A. C., 1995. Determination of dexamethasone in liver and muscle by liquid chromatography and gas chromatography/mass spectrometry. J. Agric. Food Chem. 43, 140-145.

Maurer, H. H., Tenberken, O., Kratzsch, C., Weber, A. A., Peters, F. T., 2004. Screening for library-assisted identification and fully validated quantification of 22 betablockers in blood plasma by liquid chromatography-mass spectrometry with atmospheric pressure chemical ionization. J. Chromatogr. 1058, 169-181.

Platter, W.J., Tatum, J.D., Belk, K.E., Scanga, J.A., Smith, G.C., 2003. Effects of repetitive use of hormonal implants on beef carcass quality, tenderness, and consumer ratings of beef palatability. J. Animal Sci. 81, 984-996.

Preston, R.L., 1975 Biological responses to oestrogen additives in meatproducing cattle and lambs. J. Animal Sci. 41, 1414.

Reig, M., Batlle, N., Navarro, J. L., Toldra', F., 2005. A modified HPLC method for the detection of 6-methyl-2thiouracil in cattle urine. In: Proceedings of International Congress in Meat Science and Technology, Baltimore, Maryland, August 7-12. 90p.

Roda, A., Manetta, A. C., Portanti, O., Mirasoli, M., Guardigli, M., Pasini, P., et al. (2003). A rapid and sensitive 384-well microtitre format chemiluminescent enzyme immunoassay for 19 nortestosterone. Luminesc. 18, 72-78.

Roe, F.J.G., 1976. Carcinogenicity studies in animals relevant to the use of anabolic agents in animal production. In: Anabolic Agents in Animal Production (Eds.: Lu, F.C., Rendel, J.). Environ. Qual. Safety (Suppl.). 5, 227-237.

Samarajeewa, U., Wei, C. I., Huang, T. S., Marshall, M. R., 1991. Application of immunoassay in the food industry. Crit. Rev. Food Sci. Nutr. 29, 403-434.

Stolker, A. A. M., Schwillens, P.-L.-W.J., Van Ginkel, L. A., Brinkman, U. A. Th., 2000. Comparison of different liquid chromatography methods for the determination of corticosteroids in biological matrices. J. Chromatogr. A. 893, 55-67.
Thevis, M., Opfermann, G., Schänzer, W., 2003. Liquid chromatography/electrospray ionization tandem mass spectrometric screening and confirmation methods for b2agonists in human or equine urine. J. Mass Spectr. 38, 1197-1206.

Toldra, F., Reig, M., 2006. Methods for rapid detection of chemical and veterinary drug residues in animal foods. Trends Food Sci. Technol. 17, 482-489.

Turnipseed, S. B., Roybal, J.E., Andersen, W. C., Kuck, L. R., 2005. Analysis of avermectin and moxidectin residues in milk by liquid chromatography-tandem mass spectrometry using an atmospheric pressure chemical ionization /atmospheric pressure photoionization source. Anal. Chimica Acta. 529, 159-165.

Umberger, E.J., 1975. Products marketed to promote growth in food-producing animals: steroid and hormone products. Toxicol. Environ. Qual. Safety (Suppl.) 5, 227-237.

Van Poucke, L. S. G., Depourcq, G. C. I., Van Peteghem, C., H., 1991. A quantitative method for the detection of sulphonamide residues in meat and milk samples with a high-performance thinlayer chromatographic method. J. Chromatogr. 29, 423-427.

Vanoosthuyze, K. E., Van Poucke, L. S. G., Deloof, A. C. A., Van Peteghem, C. H., 1993. Development of a high performance thin-layer chromatographic method for the multi-screening analysis of corticosteroids. Anal. Chimica Acta. 275, 177-182.

Verdon, E., Couedor, P., Roudaut, B., Sanders, P., 2005. Multiresidue method for simultaneous determination of ten quinolone antibacterial residues in multimatrix/ multispecies animal tissues by liquid chromatography with fluorescence detection: Single laboratory validation study. J. AOAC Int. 88, 1179-1192.

Wang, S., Zhang, H. Y., Duan, Z. J., Kennedy, I., 2006. Analysis of sulphonamide residues in edible animal products. Rev. Food Add. Contam. 23, 362-384.

WATT, 2011. WATT Executive Guide. To World Poultry Trends. Available at: https://www.wattagnet.com/ext/ resources/uploadedFiles/WattAgNet/Footer/Footer_Content /2011_Poultry_Trends.pdf.

Weerden, E.J., Grandadam, J.A., 1976. The effect of an anabolic agent on $\mathrm{N}$ deposition, growth and slaughter quality in growing castrated male pigs. In: Anabolic Agents in Animal Production (Eds.: Lu, F.C., Rendel, J.). Environ. Qual. Safety (Suppl.). 5, 115-122).

Yeung, R.M.W., Morris, J., 2001. Consumer perception of food risk in chicken meat. Nutr. Food Sci. 31, 270-278.

Yeung, R.M.W., Yee, W.M.S., 2002. Multidimentional analysis of consumer perceived in risk in chicken meat. Nutri. Food Sci. 3, 219-226.

\section{How to cite this article:}

Asiya, S., Akzira, O., 2016. The effect of hormones on the quality of poultry meat. Int. J. Curr. Res. Biosci. Plant Biol. 3(1), 113-121. doi: http://dx.doi.org/10.20546/ijcrbp.2016.301.012 